\title{
The microbiological contamination of an oyster growing area in Morocco: The Oualidia lagoon
}

\author{
N. Bouchriti ${ }^{(1)}$, A. El Marrakchi ${ }^{(1)}$, A. Fahim ${ }^{(2)}$ \\ (1) Département d'Hygiène et Industrie des Denrées Alimentaires d'Origine Animale (Hidaoa), \\ B.P. 6202, Institut Agronomique et Vétérinaire Hassan II, Rabat-Instituts, Rabat, Morocco \\ (2) Université Mohammed V, Faculté des Sciences, Rabat, Morocco
}

\begin{abstract}
A 3-year bacteriological survey of an oyster growing area in Morocco, where the Japanese oyster (Crassostrea gigas) is grown showed that the contamination had a tendency to increase from winter to summer. The contamination of the lagoon was not continuous but intermittent. Animal manure and human recreational activities in the vicinity of oyster growing areas were important sources of pollution. Other sources of minor importance such as the installation of spats and traditional fishing activity contribute also to the contamination of the lagoon. The major source of pollution was from animal origin except during the summer when human contamination prevailed.

Oysters harvested from this lagunar ecosystem contain fecal bacteria and may also contain bacterial pathogens. Thus, they may present a public health hazard and especially so in summer. It is hence advisable to rely oysters in clean waters or depurate them before marketing. Some control may also have to be placed on the use of the lagoon for human recreational activities to reduce the contamination during summer.
\end{abstract}

Key words. - Bacteria - Pollution - Shellfish - Seawater.

Résumé. - L'étude bactériologique d'une lagune à vocation ostréicole a montré que la contamination bactérienne des parcs d'élevage avait tendance à augmenter d'hiver en été. La lagune faisait l'objet d'une contamination intermittente. Le fumier, utilisé comme fertilisant et les activités récréatives pratiquées au voisinage des zones d'élevage sont les sources majeures de pollution. D'autres activités telles que l'installation des naissains d'huîtres et la pêche aux petits métiers contribuent aussi à la contamination de la lagune. La contamination était essentiellement d'origine animale sauf en été où la contamination humaine prévalait.

Les huîtres élevés au sein de cet écosystème lagunaire contiennent des bactéries d'origine fécale. Ils peuvent donc contenir des bactéries pathogènes et présenter ainsi un danger pour le consommateur spécialement durant la période estivale. II est donc recommandé de traiter ces huîtres par un procédé d'épuration avant leur commercialisation. Afin de réduire le niveau de contamination en été, il s'avère judicieux d'exercer un contrôle sur l'utilisation de la lagune à des fins récréatives.

Mots-clés. - Bactéries - Pollution - Coquillages - Eau de mer. 


\section{INTRODUCTION}

Shellfish including oysters, clams and mussels feed by filtering suspended particles from overlying waters. Such bivalve molluscs can accumulate and concentrate disease-causing bacteria, viruses and toxins in their bodies, if such microorganisms are present in overlying waters. This may present a human health risk because the shellfish are generally eaten raw or lightly cooked. In fact, several outbreaks of bacterial and viral diseases have been attributed to the consumption of shellfish (Gerba and Goyal, 1978; Bryan, 1980; Richards, 1987). They are also responsible for the transmission of shellfish poisoning caused by toxins produced by poisonous dinoflagellates and diatoms (Schantz, 1983; Van Egmond, 1990).

Morocco has a large coast line along the Atlantic ocean and the Mediterranean sea. Fish and shellfish are harvested at several stations along these coasts. Ostreiculture began in the early 1920's when adult oysters were imported from France and Portugal. In 1952, spat of oysters were imported from the same countries and put in pots until they reached a commercial size (Shafee and Sabatié, 1985). In 1983, in order to improve mariculture in Morocco, a large, modern aquaculture complex was built in a large lagoon in the Mediterranean coast where oysters, clams, shrimps and fish are grown. The facility included a hatchery for the production of oyster and clam spat.
This paper presents the results of a three year bacteriological study of an oyster growing area in Morocco: the Oualidia lagoon.

\section{MATERIALS AND METHODS}

\section{Area of Study}

Oualidia lagoon is situated along the Moroccan Atlantic coast, $300 \mathrm{~km}$ south of Rabat (fig. 1). The Japanese oyster (Crassostrea gigas) has adapted well to this area (Shafee, 1985). The lagoon is $7 \mathrm{~km}$ long and $0.4 \mathrm{~km}$ wide and varies betwen 0.5 and $2 \mathrm{~m}$ in depth depending upon the tide. Upstream, there are salt marshes, and downstream, the lagoon has two openings to the ocean. The average atmospheric temperatures is $12^{\circ} \mathrm{C}$ during winter and $24^{\circ} \mathrm{C}$ during summer. This lagoon is highly influenced by tidal cycles. At high tide, the lagoon is filled with the inflow of seawater and at low tide, the lagoon water runs off to the ocean (Shafee and Sabatié, 1985). It is surrounded by agricultural fields and animal pasture and is also used for recreational activities during summer.

\section{Samples and sample preparation}

Samples of lagunar seawater and oysters were collected monthly at low tide. During summer, samples were collected two to three times per month. The results are presented on a seasonal basis. Oysters were har- 


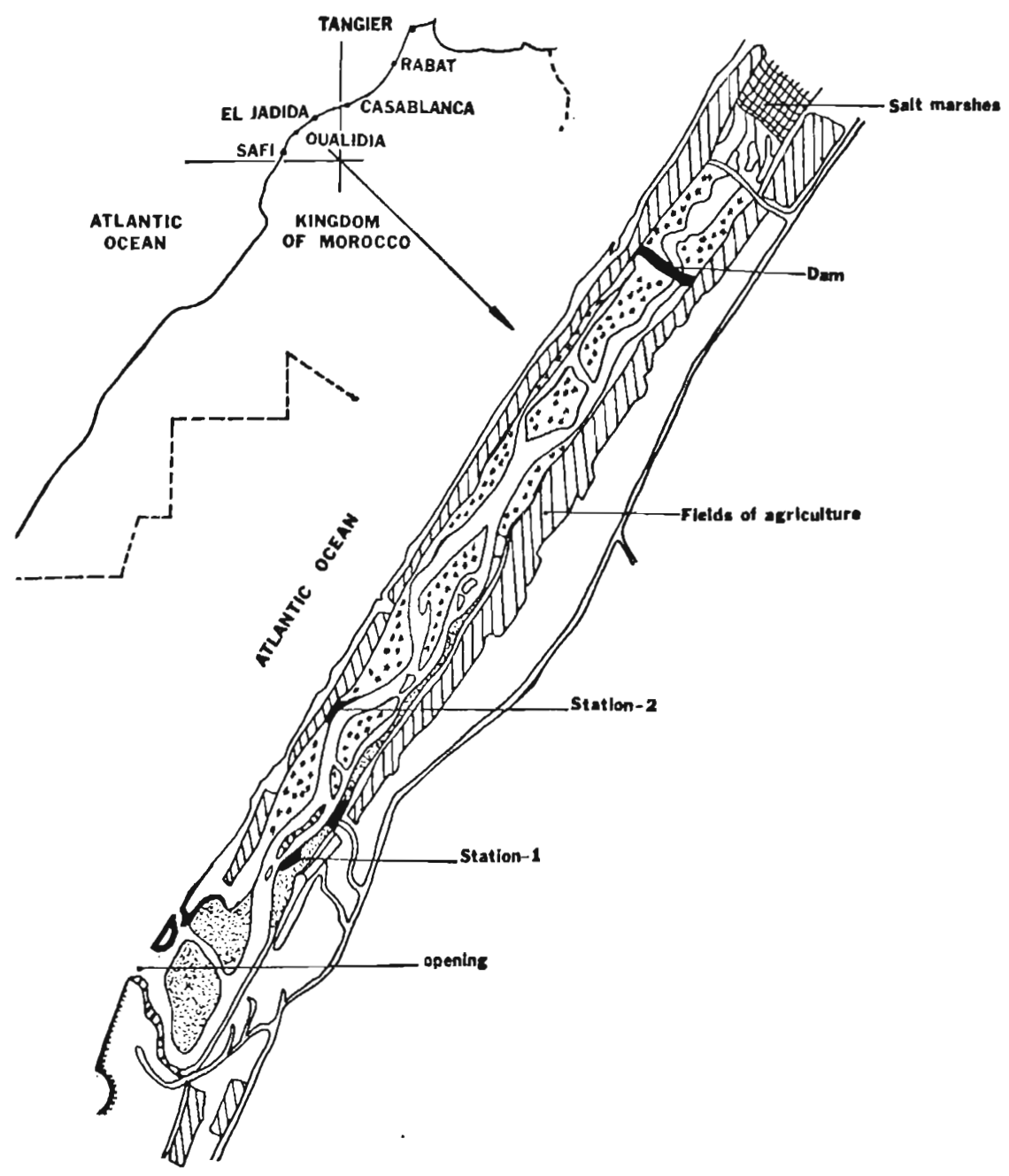

Fig. 1. - A map of Oualidia Lagoon.

vested from two stations: station 1 which is near the camping sites and station 2 which is upstream of camping activities (fig. 1). Water samples were collected at a depth of 20 to
$30 \mathrm{~cm}$ in sterile flaks. Samples were then put in a cooler and taken to the laboratory at Rabat where they were analyzed within 24 hours of collection. Twelve oysters of commercial size 
were used in each analysis. They were washed, opened, minced and blended at high speed in an ultra-turax type blender. Serial ten fold dilutions of oyster homogenate and of seawater were made in Ringer's solution.

\section{Bacterial analyses}

To determine the bacterial contamination of this lagunar ecosystem, oyster and water samples were subjected to: a) the evaluation of the global contamination by counting the total mesophilic aerobic flora; b) the appreciation of fecal contamination by counting total coliforms, fecal coliforms and fecal streptococci; c) the identification of fecal streptococci to determine the origin of contamination.

All the bacterial analyses were performed according to the standard methods for the examination of seawater and shellfish (Apha, 1970).

\section{RESULTS}

\section{Total mesophilic aerobic flora (TMAF)}

The TMAF can be used for determining the overall contamination of oysters and seawater samples. In 1986 and 1988, the bacterial loads of oysters havested from the two stations had a tendency to increase from winter to summer when the TMAF was more than $10^{5} \mathrm{CFU} / \mathrm{g}$ of oyster meat. In 1987 however, the highest bacterial counts were registered among oysters harvested in winter from station 2 and in winter and summer in those harvested from station 1 (fig. 2a). Oysters from station 2 were generally as contaminated as those from station 1 , but during summer, oysters raised at station 1 became more contaminated than those raised at station 2 (fig. 2a). The lowest bacterial loads were registered during fall. For water samples harvested from station 1, the TMAF had the same trend as in oyster samples and increased regularly from winter to summer, but in station 2 , fluctuations occured and heavy loads were found in winter. In summer, water samples harvested from station 1 were always more contaminated than those from station 2. In two instances, bacterial loads exceeded $10^{6} \mathrm{CFU} /$ $100 \mathrm{ml}$ of water (fig. 3a).

\section{Fecal streptococci (FS)}

Both oyster and water samples contained FS all year around. The trend of FS in both oyster and water samples was similar. There was an increase in FS counts from winter to summer. High counts were registered in most of the cases in summer in both water and oyster samples harvested from the two stations. These FS counts varied in the majority of the cases between $10^{3}$ and $10^{5}$ MPN/100 g for oysters (fig. 2b) and between $10^{1}$ and $10^{3} \mathrm{CFU} / 100 \mathrm{ml}$ for water samples.

\section{Total coliforms (TC)}

Total coliforms were always found in oyster samples but were absent 5 times 


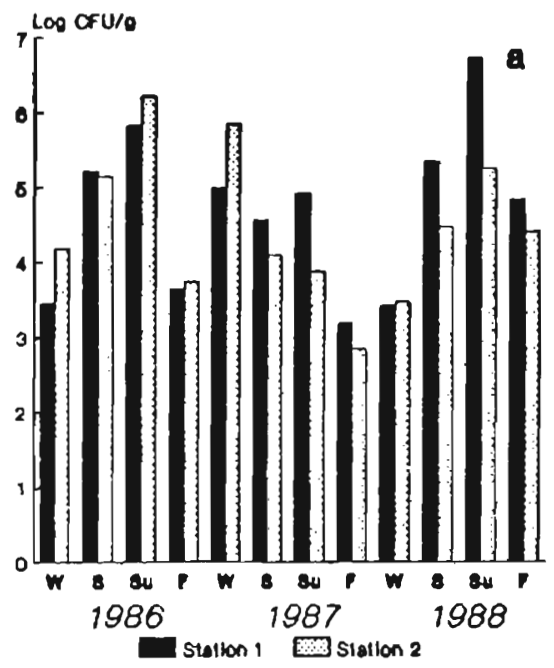

Total Coliforms

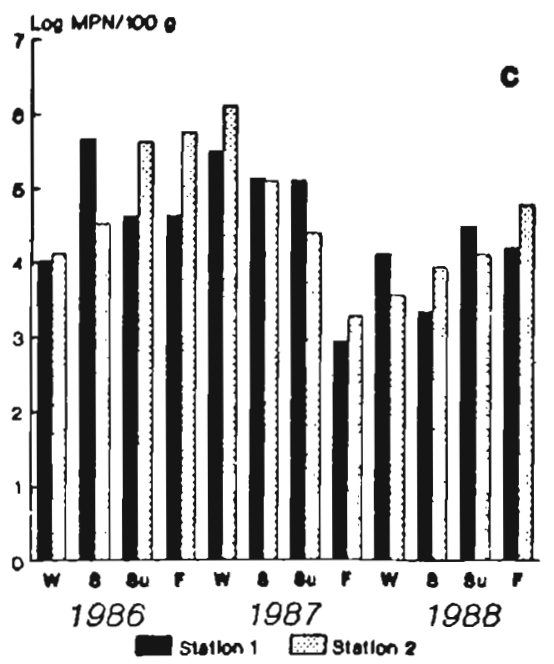

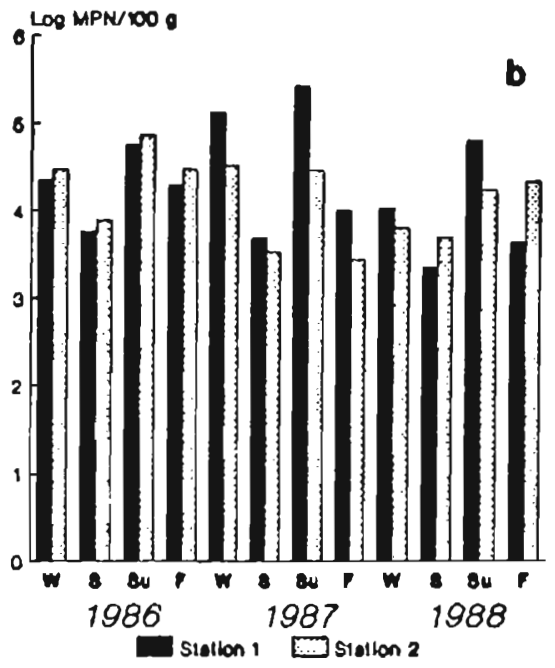

Fecal Coliforms

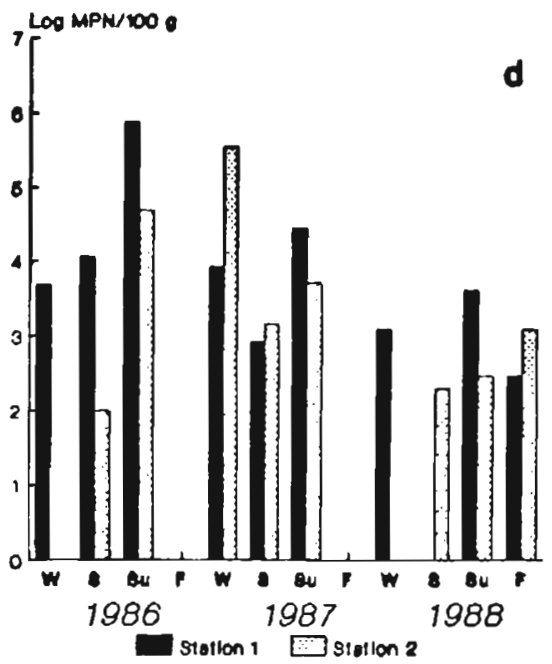

Fig. 2. - Bacteria in oyster samples. W: Winter, S: Spring, Su: Summer, F: Fall. 

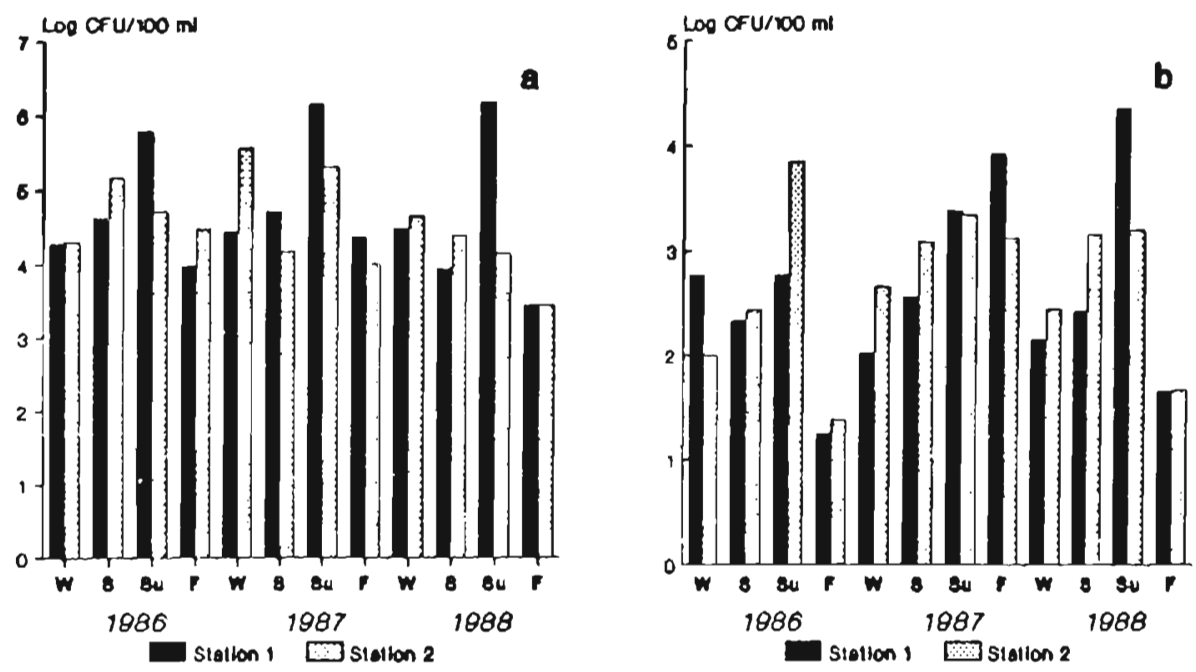

Total collforms

Fecal Coliforms
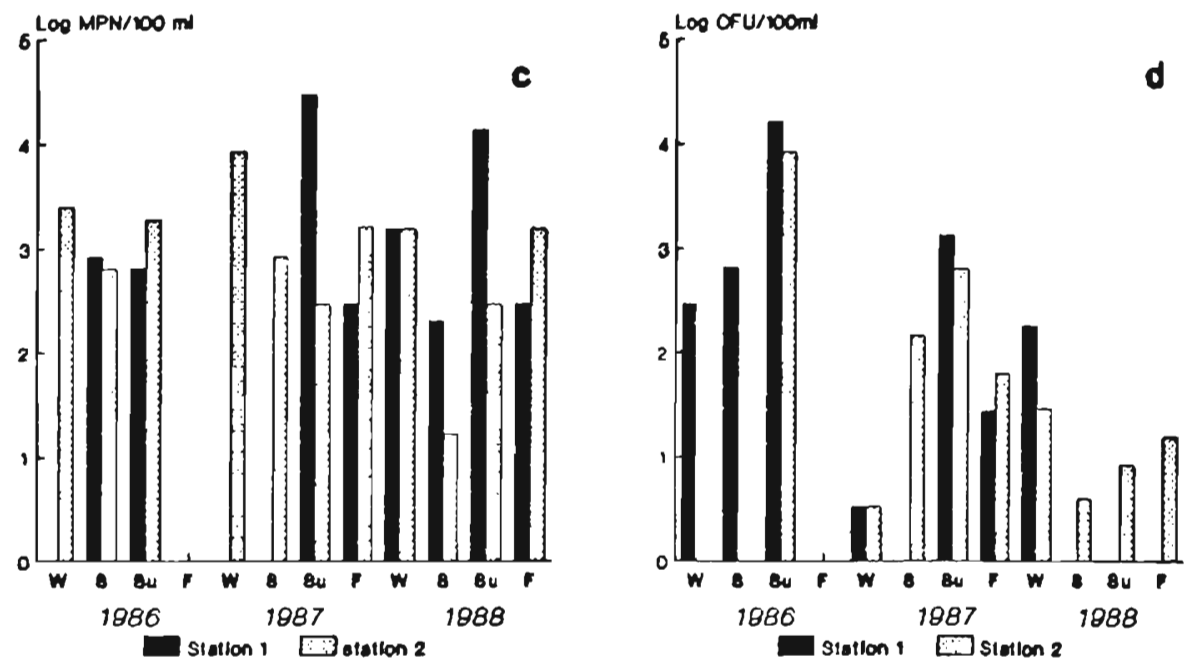

Fig. 3. - Bacteria in water samples. W: Winter, S: Spring, Su: Summer, F: Fall. 
in water samples (fig. $2 \mathrm{c}$ and $3 \mathrm{c}$ ). For water samples, the highest TC counts were registered during summers in station 1 and particularly during winter in station 2. High TC loads were found in most of the cases, in oysters harvested in winter and summer.

\section{Fecal coliforms (FC)}

On several occasions, FC were absent in both water and oyster samples (fig. 2d and 3d). For both samples, high FC counts were usually found in summers, but in 1987, the oysters harvested during winter fom the two stations were heavily loaded with FC. During summer, both water and oyster samples harvested from station 1 were more contaminated than those harvested from station 2 .

\section{Hygienic quality of lagunar sea- water and oysters}

In the absence of national standards, the United States National Shellfish Sanitation Program (US NSSP) stan- dards for shellfish growing waters were used (Apha, 1970, Wood, 1976). This standard states that "the MPN of coliforms should not exceed 70 per $100 \mathrm{ml}$ and no more than $10 \%$ of samples should exceed 230 coliforms per $100 \mathrm{ml}$ ". If we use this specification, most of the coliform-positive samples harvested from the two stations exceeded the 70 standard. Among the 81 samples of water examined, 31 exceeded it, 15 from station 1 and 16 from station 2 (table 1). If we use the US NSSP standard for market fresh, frozen an fresh-frozen oysters, mussels and clams which is a maximum fecal coliform MPN of $230 / 100 \mathrm{~g}$ of sample (Apha, 1970), it seems on the basis of $F C$ counts that more than one half $(51.9 \%)$ of oysters were above the limit, $43.9 \%$ and $52.5 \%$ from station 1 and 2 , respectively (table 1). In general, water samples were of good quality while oyster samples were of poor hygienic quality. Thus, they present a danger for the consumer and particularly those harvested in summer and winter. Furthermore,

Table I. - Hygienic quality of lagunar seawater and oysters.

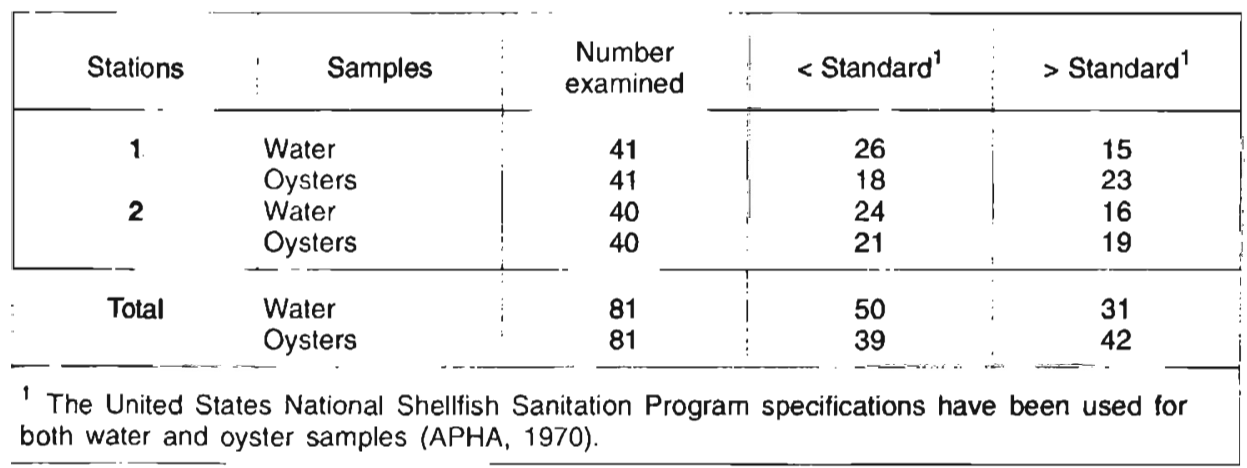


they are susceptible to contain pathogens because the presence of indicator bacteria may indicate the presence of pathogenic bacteria (Brisou and Denis, 1978; Geldreich, 1978; Robertson, 1984). Such a situation makes it necessary to determine the origin of contamination because a contamination by human enteric microorganisms may be more dangerous for the consumers.

\section{Origin of contamination}

For water samples, it is possible to determine whether the contamination is from animal or human origin by using the FC/FS ratio (Geldreich, 1978). A ratio of less than 0.7 indicates that the pollution is derived predominantly or entirely from animal sources and a value exceeding 4 indicates that the pollution is exclusively derived from urban residues. When these ratios were applied to our samples, it seemed that the majority of fecal contamination was of animal origin except in the summer of 1986 when the contamination was exclusively from human origin at station 1 (table 2). One should, however, be careful in using the FC/FS ratio which is valuable only when the contamination is recent (Borrego and Romero, 1982; Geldreich, 1978). Because FS persist longer than FC in seawater, this ratio decreases progressively after the discharge of bacteria to seawater. A specific indication of animal pollution of water can be shown by the presence of Streptococcus bovis and Streptococcus equinus which are specific to animal feces and do not normally

Table II. - FC/FS ratios for water samples ${ }^{a}$

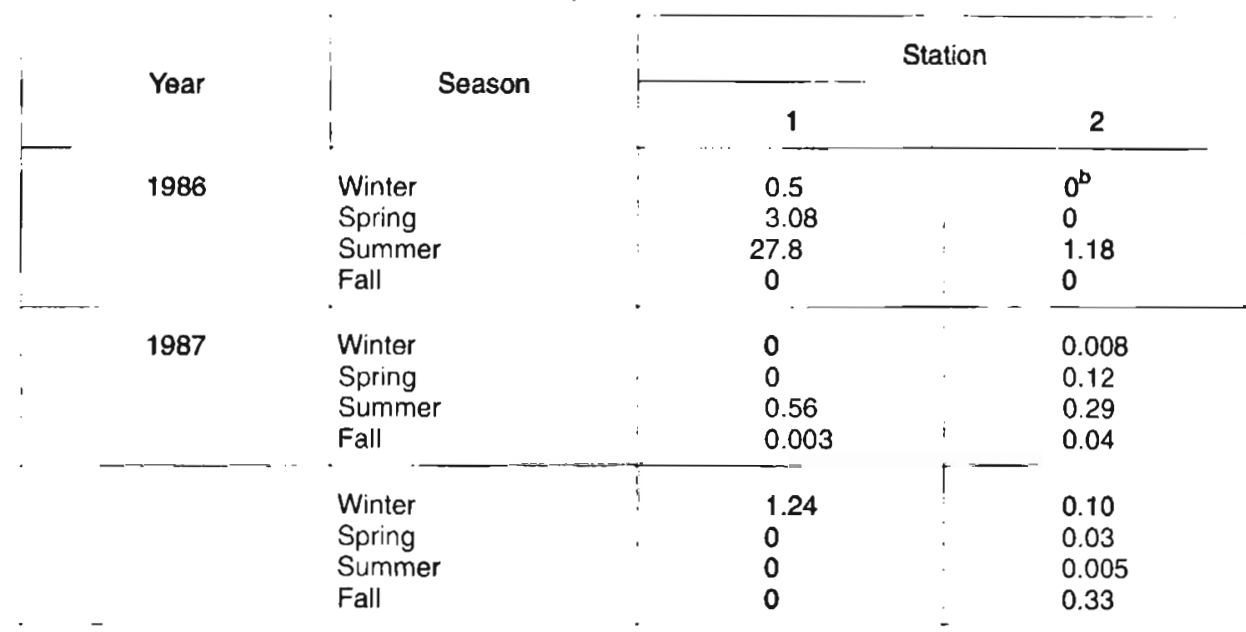

$\begin{array}{ll}\text { Year } & \\ & \\ 1986 & \text { Winter } \\ & \text { Spring } \\ & \text { Summer } \\ & \text { Fall } \\ & \text { Weason } \\ & \text { Winter } \\ & \text { Spring } \\ & \text { Summer }\end{array}$

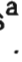

a Data shown are from samples when both fecal coliforms (FC) and fecal streptococci (FS) were simultaneously present.

- Samples were negative for FC. 
occur in human excreta (Geldreich, 1978). Thus 215 strains of FS isolated from both water and oyster samples were speciated.

\section{Fecal Streptococci indentification}

Three species were found: Streptococcus faecalis (84 strains), Streptococcus faecium (70) and Streptococcus bovis (61) (table 3). In water samples, $S$. bovis was more frequently isolated. Its presence in both stations indicates the animal origin of pollution because this species is a normal flora of the gastrointestinal tract of bovids and other warm-blooded animals (Buttiaux et al., 1974; Brisou and Denis, 1978). The animal pollution was more accentuated in station 2 since $S$. bovis constituted $57.1 \%$ of the isolates but only $27.5 \%$ in station 1. This species was found more in winter and completely absent in summer (fig. 4 and 5). This is explained by the fact that this species fairly withstands the conditions of the marine environment and rapidly disap- pears outside the intestine. Its presence indicated a recent contamination and showed that the lagoon was effectively subjected to a continuous animal pollution which decreased or disappeared in summer. S. bovis constituted only $17.5 \%$ of the FS isolated from oyster samples. This low number could be attributed to the detrimental effects in the gastrointestinal tract of shellfish on the survival of this species (Plusquelec et al., 1986).

Unlike $S$. bovis, $S$. faecalis was found at high frequencies during summer and particularly in station 1 (fig. 4 and 5). This species is a normal flora of the gastrointestinal tract of man and animals. Its presence indicates that contamination could have originated from both these sources. But, since there were no $S$. bovis, it could then be concluded that the origin of $S$. faecalis in this period is from human. Its presence at high frequencies in oyster samples (fig. 5) is reflective of its adaptation to the hostile conditions of their gastrointestinal tract (Plusquelec et al., 1986).

Table III. - Number of fecal streptococci species identified in water and oyster samples

\begin{tabular}{|l|c|c|c|c|c|}
\hline Samples & Stations & S. faecalis & S. faecium & S. bovis & Total \\
\hline Water (W) & 1 & 17 & 12 & 11 & 40 \\
Oysters (O) & 2 & 8 & 13 & 28 & 49 \\
& 1 & 33 & 25 & 5 & 63 \\
\hline Total & 2 & 26 & 20 & 17 & 63 \\
\hline Total & W & 25 & 25 & 39 & 89 \\
\hline
\end{tabular}




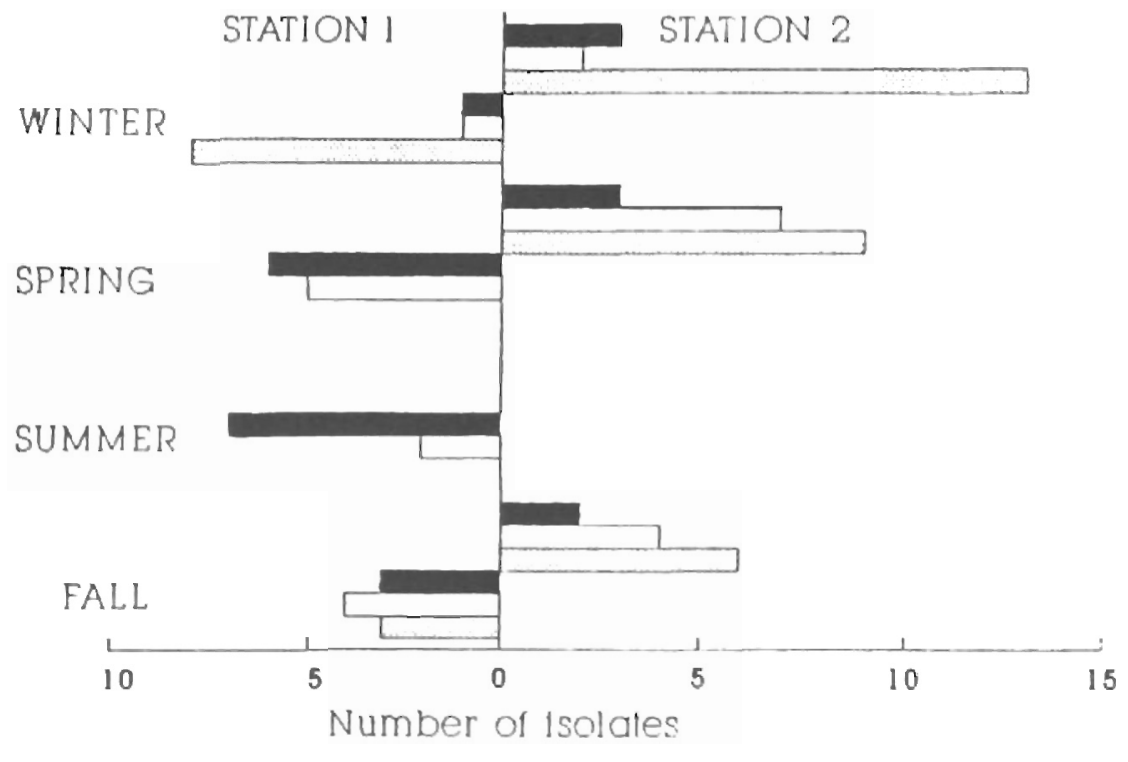

Streptococcus faecalis

$\square$ Streptococcus faecium

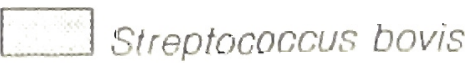

Fig. 4. - Seasonal distribution of fecal Streptococci in water samples.

\section{DISCUSSION}

This survey of the Oualidia lagoon indicated that the TMAF was present in water and oyster samples all year long and had a tendency to increase from winter to summer. Relatively high counts of all flora during the summer can be partly explained on the basis of oyster physiology. During summer, oysters have a higher capacity for wa- ter filtration and may retain increased levels of contamination in their bodies. Human recreational activities in the vicinity of oyster growing areas during summer may also increase the pollution load. As mentioned earlier, the lagoon is highly influenced by tidal cycles. At high tide, the ocean water may bring to the lagoon all human wastes accumulated during camping. Thus, station 1, which is near the 


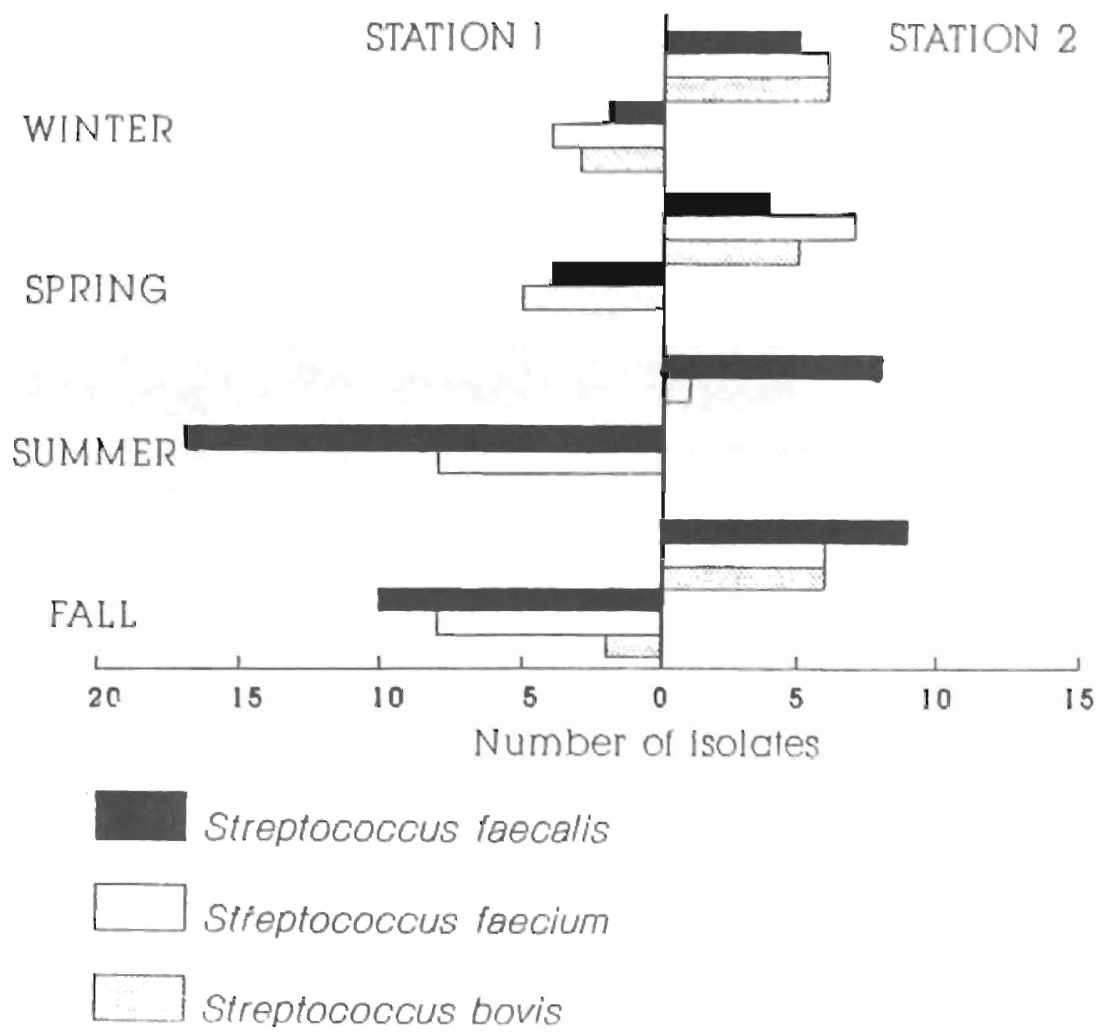

Fig. 5. - Seasonal distribution of fecal streptococci in oyster samples.

camping sites downstream of the lagoon, became more contaminated during summer than station 2 which is upstream of camping activities. Since there are no sewage outfalls emptying into the lagoon, the human fecal pollution could have originated only from the recreational activities, as shown by the FC/FS ratio and the identification of fecal streptococci. Hence, the lagoon should be subjected to a strici control during the summer.

Heavy loads of all bacteria in 1987 appear to be due to the heavy rainfall that occured that year. The lagoon is surrounded by agricultural fields and animal pastures. After rainfall, manure is drained and the soil is washed by water, thus contaminating the lagoon. The participation of manure in the contamination of the lagoon is important because more than 120 tons are used each year to fertilize the 34 hectares surrounding the lagoon ( $E$ I Bouzaïdi, 1986). On several occasions, high fecal coliform counts were immediately followed by very low counts or even the absence of these bacteria. 
This may have been due to the depuration ability of oysters and to the limited survival of fecal coliforms in seawater. Frequent fluctuations in bacterial counts indicated that this oyster raising area was subjected to an intermittent fecal pollution. The application of the US NSSP standards showed that both water and oyster samples exceeded them on several occasions and particularly those harvested during summer. Thus, oysters harvested from this lagoon may present a public health hazard at any season of the year and especially so in summer.

Other sources of minor importance contribute also to the contamination of the lagoon and particularly the installation of spats and traditional fishing activity. A previous study showed that spats contained high levels of bacteria which have developed during transportation (Beaubrun, 1972). Furthermore, their installation provokes an increase in the pollution by resuspension of large quantities of fluffy sediments which constitutes an ecological "reservoir" for a variety of microorganisms (Brisou et Denis, 1978). On the other hand, the professional fishing season spans the period from April to September. Fishermen position their small fishing vessels in the vicinity of the lagoon. Such activity may also contribute to the pollution of the lagoon. According to these findings, it is then possible to draw a scheme for all the sources contributing to the pollution of this lagunar ecosystem (fig. 6).

\section{अध अ \\ Recreationnal activitles: Camplng. Bathing}

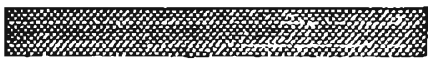

Fishing acilvilles
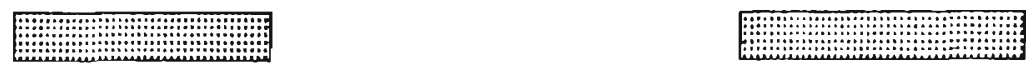

Agriculture acllvitles: Manure fertilization. Grazing

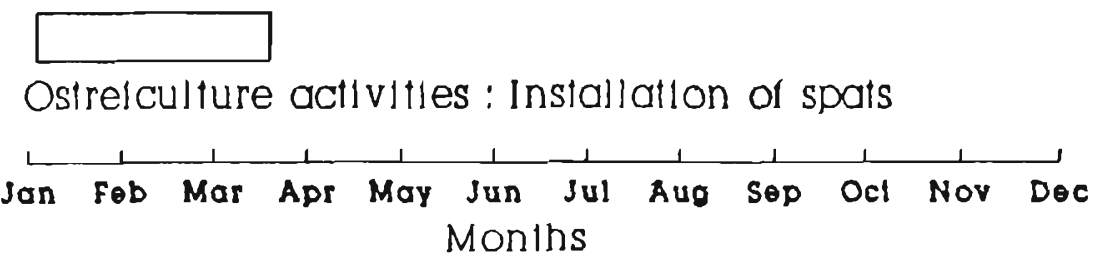

Fig. 6. - The different sources of pollution of the lagoon. 


\section{CONCLUSION}

It is reasonable to assume that, in the near future, the industry of aquaculture will flourish in Morocco. At the present time, we do not have informations about the role of shellfish in the transmission of diseases in Morocco. Only one well documented outbreak of paralytic shellfish poisoning following the consumption of mussels harvested after a red tide has been described. This outbreak involved 114 victims of which 9 died (Karege, 1979).

The present study has shown that the oysters harvested from Oualidia lagoon contain fecal indicator bacteria and may also contain human pathogens. The absence of fecal bacteria may not assure the safety of shellfish because these bacteria are not adequate in indicating the virological quality of water and shellfish. Thus, human enteroviruses have been isolated from both open and closed areas for shellfishing (Goyal et al., 1979). Moreover, outbreaks of viral hepatitis A occured following the consumption of shellfish meeting the current bacteriological standards (Portnoy et al., 1975). It is necessary therefore to assure the safety of shellfish, shellfish raising waters and recreational areas so that people using these important resources are not subjected to any health risks. This will involve monitoring of these resources on a routine basis Shellfish found contaminated with bacteria and/or viruses can then be depurated. Depuration refers to the ability of bivalve mollusks to cleanse themselves of ex- traneous matter when they are placed in clean fresh water ( $\mathrm{Di}$ Girolamo, 1983). The routine use of this practice in this lagoon may contribute to the decrease of pollutants accumulated by oysters. Some control may also have to be placed on the use of the lagoon for human recreational activities.

\section{REFERENCES}

APHA, 1970. Recommended procedures for the examination of seawater and shellfish, $4^{\mathrm{e}}$ ed. American Public Health Association. Washington DC.

Beaubrun P.C., 1972. L'état bactériologique des parcs ostréicoles et des coquillages de la lagune de Oualidia au cours de l'année 1970. Bull. Inst. Pêches Maritimes. No. 20.

Borrego A.F. et Romero P., 1982. Study of the microbiological pollution of a Malaga littoral area. II. Relationship between fecal coliforms and fecal streptococci. VIe Journées Etud. Pollutions. Cannes. France. 2-4 Décembre: 561-569.

Brisou J.F. et Denis F.A., 1978. Hygiène de l'environnement maritime. Masson. Paris.

Bryan F.L., 1980. Epidemiology of foodborne diseases transmitted by fish, shellfish and marine crustaceans in the United States, 1970-1978. J. Food Prot., 43: 859-876.

Buttiaux R., Beerns $H$. et Tacquet A., 1974. Manuel de techniques bactériologiques, $4^{e}$ ed. Médecine-Sciences. Flammarion.

Di Girolamo R., 1983. Food contaminants: Enteric pathogens in shellfish. Handbook of foodborne diseases of biological origin. M. Rechcigl, Jr. ed.: 257-269. CRC Press. Boca Raton. Florida.

El Bouzaïdi D.A., 1986. Variation spatiotemporelle des paramètres physico- 
chimiques et biologiques de la lagune de Oualidia. Mémoire Halieutique. Institut Agronomique et Vétérinaire Hassan II. Rabat. Maroc.

Geldreich E.E., 1978. Bacterial populations and indicator concepts in feces, sewage, storm water and solid wastes. Indicators of viruses in water and food. G. Berg ed.: 4-97. Ann Arbor Publishers. Ann Arbor. MI.

Gerba C.P. et Goyal S.M., 1978. Detection of viruses in shellfish: a review. J. Food Prot., 41: 743-754.

Goyal S.M., Gerba C.P. et Melnick J.L., 1979. Human enteroviruses in oysters and their overlying waters. Appl. Environ. Microbiol., 37: 572-581.

Karege C., 1979. Contribution à l'étude de la pollution d'une embouchure sur le littoral Atlantique Marocain: L'embouchure de Bouregreg. Thèse de Doctorat Vétérinaire. Institut Agronomique et Vétérinaire Hassan II. Rabat. Maroc.

Plusquelec A., Beucher M. et Le Gal Y., 1986. Bivalves: indicateurs de pollution microbienne des eaux littorales. IFREMER. Actes Colloques, 75: 19-24.

Portnoy B.L., Mackowiak P.A., Caraway C.T., Walker J.A., McKinley T.W. et Klein Jr (J.A.), 1975. Oyster-associated hepatitis: Failure of shellfish certification programs to prevent outbreaks. J. Am. Med. Assoc., 233: 1065-1068.
Richards G.P., 1987. Shellfish-associated virus illness in the United States, 1934-1984. Estuaries, 10: 84-85.

Robertson W.J., 1984. Pollution indicators and potential pathogenic microorganisms in estuarine recreational waters. Can. J. Pub. Health, 75: 19-24.

Sabatié M.R. et Shafee M.S., 1982. Etude préliminaire du rôle de quelques paramètres écologiques sur la croissance des huîtres dans la lagune de Oualidia. Maroc. Actes Inst. Agro. Vet. (Maroc), 2: 74-90.

Schantz E.J., 1983. Paralytic shellfish poisoning. Handbook of foodborne diseases of biological origin. $M$. Rechcigl, Jr. ed.: 497-499. CRC Press. Boca Raton. Florida.

Shafée M.S., 1985. Biological adaptation of the Pacific oyster (Crassostrea gigas) in Oualidia lagoon (Morocco). Aquacultural Meeting in Africa. Kisumu. Kenya. 7-11 October: 27 pp.

Shafée M.S. et Sabatié M.R., 1985. Croissance et mortalité des huitres dans la lagune de Oualidia. Aquaculture, 53: 201-214.

Van Egmond H.P., Speijers G.J.A. et Wouters R.B.M., 1990. Naturally occuring toxicants in foodstuffs. 3. Phycotoxins. Food Lab. News, 22: 41-49.

Wood P.C., 1976. Guide to shellfish hygiene. World Health Organization. Geneva. Switzerland. 